2. To: (Receiving Organization)

See distribution list

5. Proj./Prog./Dept./Div.;

Remove SNM from PFP

8. Originator Remarks:

This is the initial release of this project plan.

11. Receiver Remarks: 11A. Design Baseline Document? $\mathrm{Q}$ Yes $\mathrm{B}$ No
3. From: (Originating Organization) PFP Program Management 6. Design Authority/ Design AgentCog.Engr.: W. D. Bartlett

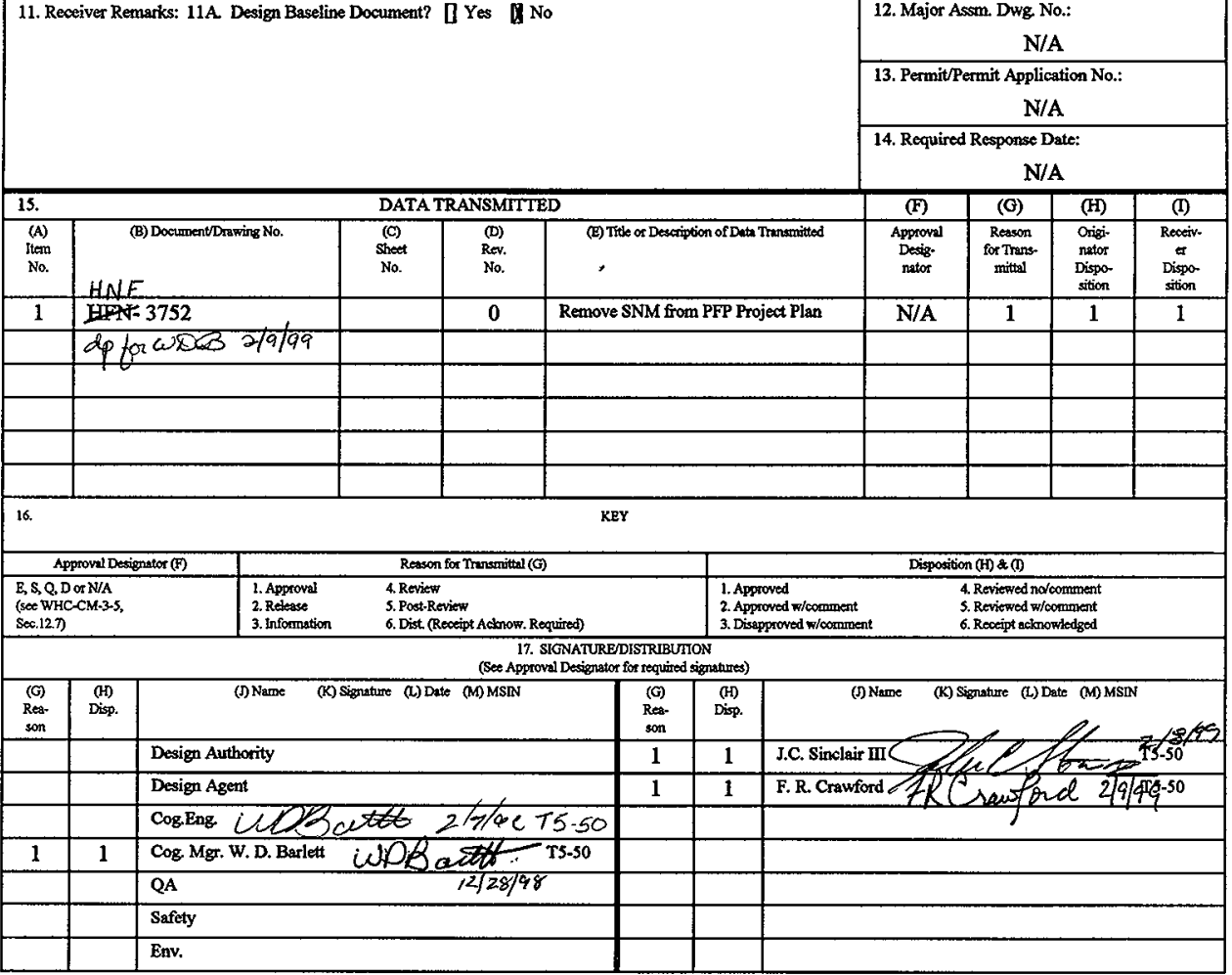

\begin{tabular}{|c|c|c|c|}
\hline $\begin{array}{l}18 . \\
\text { WOPaatat } \\
\text { Signature of } \mathrm{BDT} \\
\text { Originator }\end{array}$ & 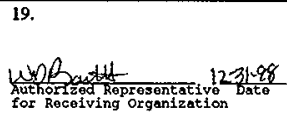 & 20. & $\begin{array}{l}\text { 21. DOE APPROVAL (if required) } \\
\text { Ctrl. No. } \\
\text { [] Approved } \\
\text { [] Approved w/ comments } \\
\text { [] Di sapproved w/ comments }\end{array}$ \\
\hline
\end{tabular}

BD-7400-172-2 (05/96) GEE097 
HNF-3752, Rev. 0

$\infty$

\title{
Project Plan \\ Remove Special Nuclear Material from PFP Project Plutonium Finishing Plant
}

\author{
W. D. (Dean) Bartlett
}

B\&W Hanford Company, Richland, WA 99352

U.S. Department of Energy Contract DE-AC06-96RL13200

EDT/ECN: 612495

UC: 2050

Org Code: 15000

Charge Code: 100749/AA30

B\&R Code: EW7040000

Total Pages: 14

Key Words: Project Management Plan, Remove Special Nuclear Material from PFP

Abstract: Project Management Plan for the transfer of Special Nuclear Material located at PFP to their final storage destination.

TRADEMARK DISCLAIMER, Reference herein to any specific commercial product, process, or service by trade name, trademark, manufacturer, or otherwise, does not necessarily constitute or imply its endorsement, recommendation, or favoring by the United States Government or any agency thereof or its contractors or subcontractors.

Printed in the United States of America. To obtain copies of this document, contact: Document Control Services, P.O. Box 950, Mailstop H6-08, Richland WA 99352, Phone (509) 372-2420; Fax (509) 376-4989.

DOES NOT CONTAIN CLASSIFIED OR

UNCLASSIFIED CONTROLLED

NUCLEAR R.FORATION

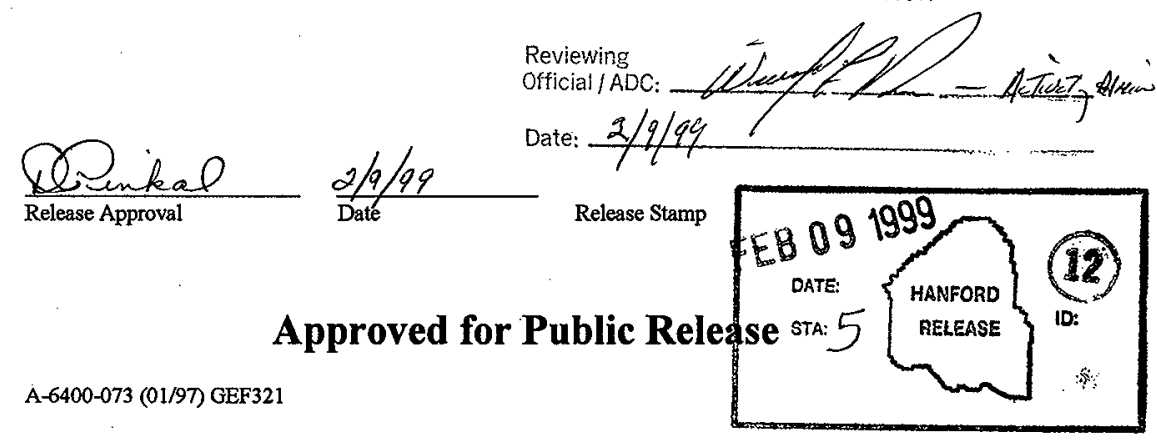




\section{TABLE OF CONTENTS}

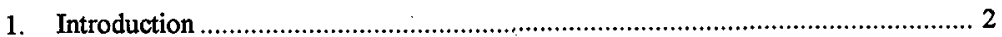

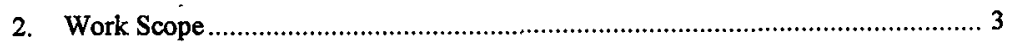

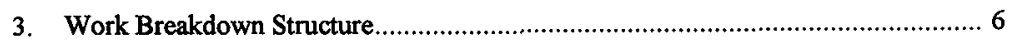

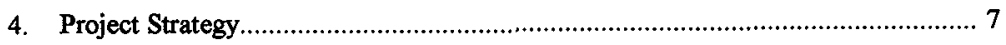

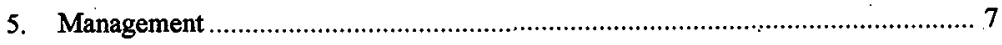

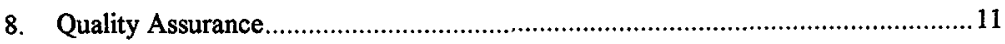

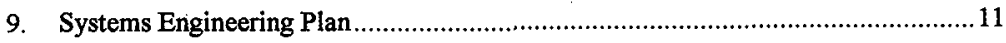

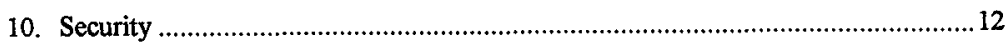

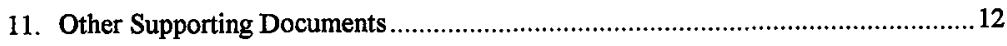

\section{LIST OF FIGURES}

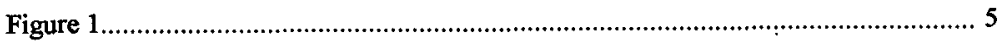

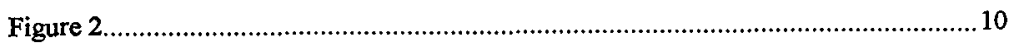

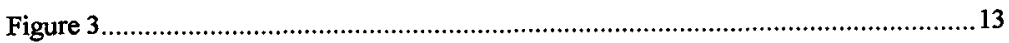




\section{Project Plan \\ Remove Special Nuclear Material from PFP Project \\ Plutonium Finishing Plant \\ November 16, 1998}

1. Introduction

\subsection{Project Plan Purpose}

This plan presents the overall objectives, description, justification and planning for the Plutonium Finishing Plant (PFP) Remove Special Nuclear Material (SNM) Materials. The intent of this plan is to describe how this project will be managed and integrated with other facility stabilization and deactivation activities. This plan supplements the overall integrated plan presented in the Plutonium Finishing Plant Integrated Project Management Plan (IPMP), HNF-3617, Rev. 0.

This project plan is the top-level definitive project management document for PFP Remove SNM Materials project. It specifies the technical, schedule, requirements and the cost baselines to manage the execution of the Remove SNM Materials project. Any deviations to the document must be authorized through the appropriate change control process.

\subsection{Project Description}

The Remove SNM Materials project provides the necessary support and controls required for U.S. Department of Energy (DOE)-Headquarters (HQ), DOE, Richland Operations Office (RL), B\&W Hanford Company (BWHC), and other DOE Complex Contractors the path forward to negotiate shipper/receiver agreements, schedule shipments, and transfer material out of PFP to enable final deactivation.

\subsection{Project Mission}

This project is part of the PFP Stabilization and Deactivation Project. The Stabilization and Deactivation Project is discussed in the Hanford Site Integrated Stabilization Management Plan (SISMP) and the PFP IPMP. The overall project mission is provided in the IPMP.

The mission of the of the Remove SNM Material project from the PFP is to stabilize, provide interim storage, package and ship plutonium $(\mathrm{Pu})$ bearing material to the designated receiver sites for long term storage or finial disposition. 


\subsection{Project Background}

The driving force behind this project is the Record of Decision that calls for all material to be stabilized to the DOE-STD-3013 standard and shipped to the Savannah River Site (SRS) for long term storage until the Material Disposition facility is completed. (In a 3013 bagless or like container.)

\subsection{Project Relationship to the Total Stabilization Program}

This project is one of several identified to complete stabilization of plutonium at PFP, safely store it onsite, ship it offsite for storage or disposal, and transition the facility to a condition suitable for long term, minimum cost surveillance and maintenance. The overall hierarchy of planning documents is as follows:

- IPMP, presents the overall planning strategies and scope for the above.

- Project planning at the functional level

- Facility Surveillance and Maintenance

- Material Storage (vaults)

- International Atomic Energy Agency (IAEA) support activities

- Material Stabilization

- Project Planning to support Material Stabilization activities

- Metals and Oxides Stabilization

- Solutions Stabilization

- Polycubes Stabilization

- Residues Disposition

- Project W-460, Plutonium Stabilization and Packaging (PuSAP) construction

- Plutonium Stabilization and Handling (PuSH) Operations

- Fuels Management

- SNM

- Special Isotopes

- Facility Transition

- Material Shipments (this plan)

- Post Deactivation Surveillance and Maintenance

2. Work Scope

\subsection{Work Scope}

\section{Process Flow Description}

Figure 1 provides (1) the major process steps associated with the Removal of SNM Material project and (2) the overall relationships to the Defense Nuclear Facilities Safety Board (DNFSB) Recommendation 94-1 activities. Material stored in room 3 of the $2736-\mathrm{Z}$ Building will be 
HNF-3752, Rev. 0

stabilized and packaged to 3013 criteria. Interim storage will be provided if the Plutonium Stabilization and Packaging (PuSAP) facilities are not available. Final packaging to DOE-STD-3013 criteria for long term storage and shipment to the SRS will be provided following PuSH processing activities.

\section{Facility Modifications/Equipment Installation}

No additional facility modifications or equipment installation will be required. 


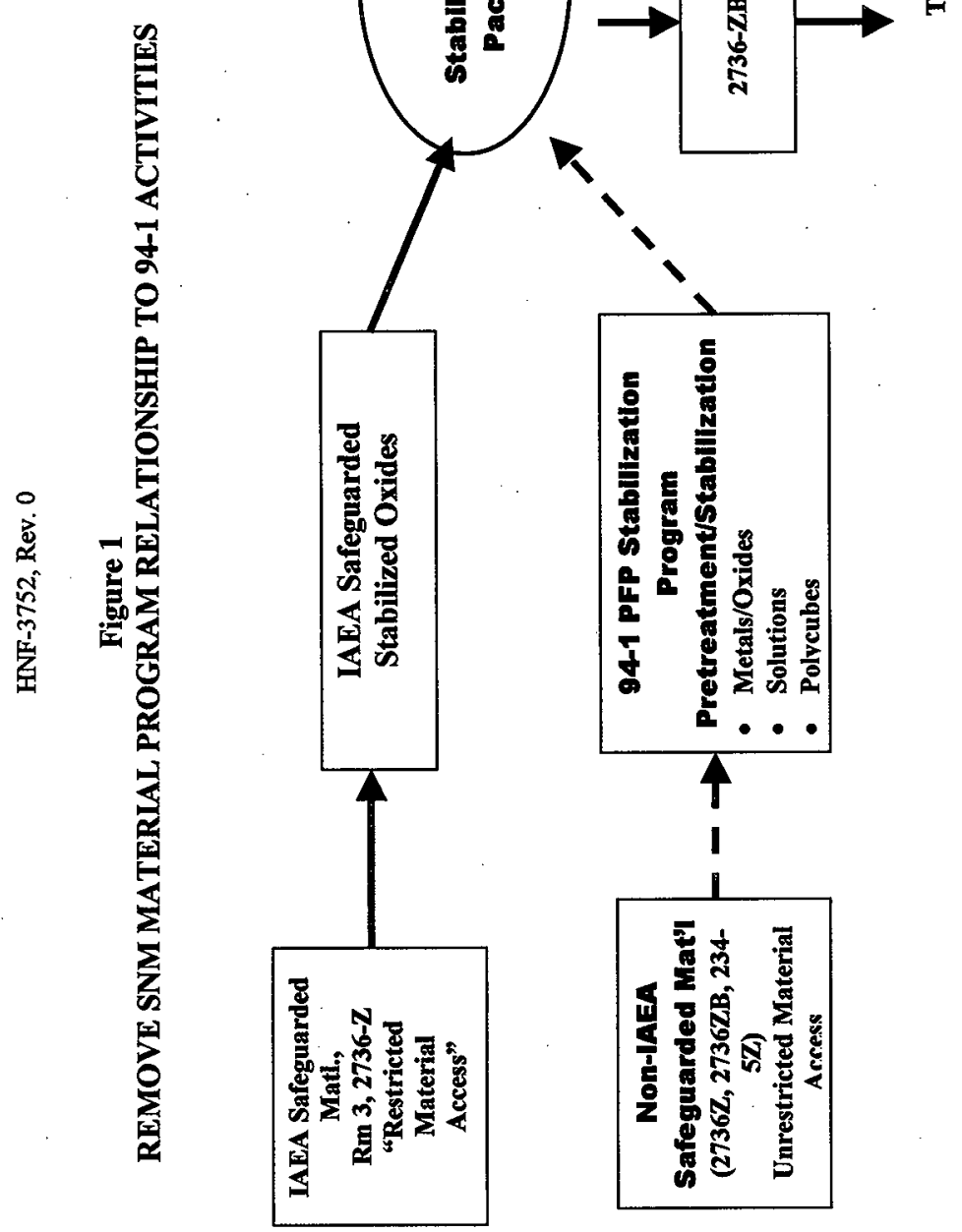


HNF-3752, Rev. 0

\section{Operations}

This work scope includes support to DOE-HQ and RL in negotiating shipper/receiver plans with other DOE Contractors.

\subsection{Requirements Baseline}

\subsubsection{Driving Requirements}

Driving requirements are those requirements that define the project mission. The DNFSB Recommendation 94-1 Hanford Site Integrated Stabilization Management Plan (SISMP), revision 5, dated May 1997 has been the source of driving requirements for the PFP projects.

\subsubsection{Derived Requirements}

Derived requirements are those requirements that flow down from higher level requirements or assumptions. No derived requirements have been identified at this time.

\subsubsection{Key Interfaces}

Each of the tasks included in this project have a shipping and packaging interface which includes the PuSAP Stabilization and Packaging to DOESTD-3013 and SRS or Los Alamos National Laboratory (LANL) packaging and shipping standards. It is assumed that it will be possible to establish each of these interfaces as currently planned.

Due to the possibility of several related processes going on at the same time, this project will have interfaces with the other subprojects. These interfaces include items such as material flow, feed and stabilized material transfers, staging, radiation effects, and airborne radiation area status. Evaluations of the material flow to the different DNFSB Recommendation 94-1 operations and the interactions between them will need to be conducted as required to ensure a smooth flow of material.

\subsubsection{Key Milestones}

Complete removal of SNM by fiscal year 2007.

\section{Work Breakdown Structure}

The Remove SNM Material Project Work Breakdown Structure (WBS) is shown in Section 5.3. The WBS is a product-oriented hierarchy of the work and products for the subproject and will be used to define and inter-relate the subproject work. 
4. Project Strategy

The Remove SNM Material Project will complete packaging and shipment of the material to its finial storage location. The strategy for this project is to complete the work within the current project management structure, minimize impacts to the other projects' tasks and complete the shipments as efficiently as possible.

\section{Management}

The Remove SNM Material project is under the direction of PFP Senior Director.

Support for the subproject activities is provided by various support groups within the PFP organization.

\subsection{Project Management Roles and Responsibilities}

The individual cost account packages for this subproject are identified in Section 5.3 .

\subsubsection{Project Manager}

The project manager is responsible for the following activities within this subproject:

- Planning, managing and maintaining the technical, schedule, and cost baselines for the project.

- Selecting and directing cost account managers responsible for delivering discrete products and services defined by assigned WBS elements.

- Maintaining a trained and qualified work force to complete the cost account products.

- Effectively resolving issues impacting project completion.

- Providing monthly project status of performance to the PBS manager.

- Acting as primary point of contact for all issues pertaining to the project

- Obtaining and directing other support functions necessary to ensure project completion.

- Providing effective personnel resources utilization.

\subsubsection{Cost Account Managers}

The individual cost account managers are responsible for the following:

- Planning and completing the applicable cost account work scope in accordance with the technical, schedule and cost baselines established in this plan.

- Identifying work package managers as needed and ensuring that their work is properly managed to achieve control account objectives.

- Performing work in a manner that meets the subproject's quality objectives.

- Ensuring resource requirements are identified to matrix organizations. 
- Maintaining a trained and qualified work force to complete the cost account products.

- Achieving operational safety and compliance with permit requirements.

- Evaluating and reporting monthly cost account status to the project manager.

- Maintaining required operational efficiencies to achieve project objectives.

- Developing and implementing corrective action plans as needed.

- Directing and working with work package managers to complete the work packages as planned.

\subsection{Primary Project Interfaces}

Primary project interfaces are shown in Figure 2.

5.3 Responsibility Assignment Matrix

\begin{tabular}{|l|l|l|}
\hline \multicolumn{1}{|c|}{ WBS } & \multicolumn{1}{|c|}{ TITLE } & \multicolumn{1}{|c|}{$\begin{array}{c}\text { RESPONSIBLE } \\
\text { MANAGER }\end{array}$} \\
\hline 1K6BL1 & Project Management Min Safe & W. D. (Dean) Bartlett \\
\hline 1K6BA1 & Shipments of SNM & W. D. (Dean) Bartlett \\
\hline 1K6EA1 & $\begin{array}{l}\text { Offsite SNM Shipment \& } \\
\text { Receipt }\end{array}$ & W. D. (Dean) Bartlett \\
\hline 1K6EA2 & $\begin{array}{l}\text { Onsite SNM Shipment \& } \\
\text { Receipt }\end{array}$ & W. D. (Dean) Bartlett \\
\hline 1K6EA3 & $\begin{array}{l}\text { Vault Miscellaneous } \\
\text { Maintenance }\end{array}$ & W. D. (Dean) Bartlett \\
\hline 1K6EA4 & Vault \#3 Security Maintenance & W. D. (Dean) Bartlett \\
\hline 1K6BL1 & Vault Project Management & W. D. (Dean) Bartlett \\
\hline
\end{tabular}

5.4 Authority/Responsibility Matrix

Authority and responsibilities for this project are summarized in Figure 2 and Section 5.3 of this project plan.

6. Schedules (Baseline)

The Remove SNM Material project schedule is provided in Figure 3. Detailed schedules will be developed and/or updated and will be maintained in Primavera Project Planner (P3). 
HNF-3752, Rev. 0

\section{Cost Estimate}

The funding requirements for this project are listed in the following table.

\begin{tabular}{|c|c|}
\hline FISCAL YEAR & $\begin{array}{l}\text { FUNDING REQUIREMENT } \\
(\$ K)\end{array}$ \\
\hline 1999 & 1,815 \\
\hline 2000 & 1,815 \\
\hline 2001 & 1,815 \\
\hline 2002 & TBD \\
\hline 2003 & TBD \\
\hline 2004 & TBD \\
\hline 2005 & TBD \\
\hline 2006 & TBD \\
\hline 2007 & TBD \\
\hline 2008 & TBD \\
\hline 2009 & TBD \\
\hline 2010 & TBD \\
\hline 2011 & TBD \\
\hline 2012 & TBD \\
\hline 2013 & TBD \\
\hline 2014 & TBD \\
\hline 10 & TBD \\
\hline
\end{tabular}


Figure 2

Primary Project Interfaces

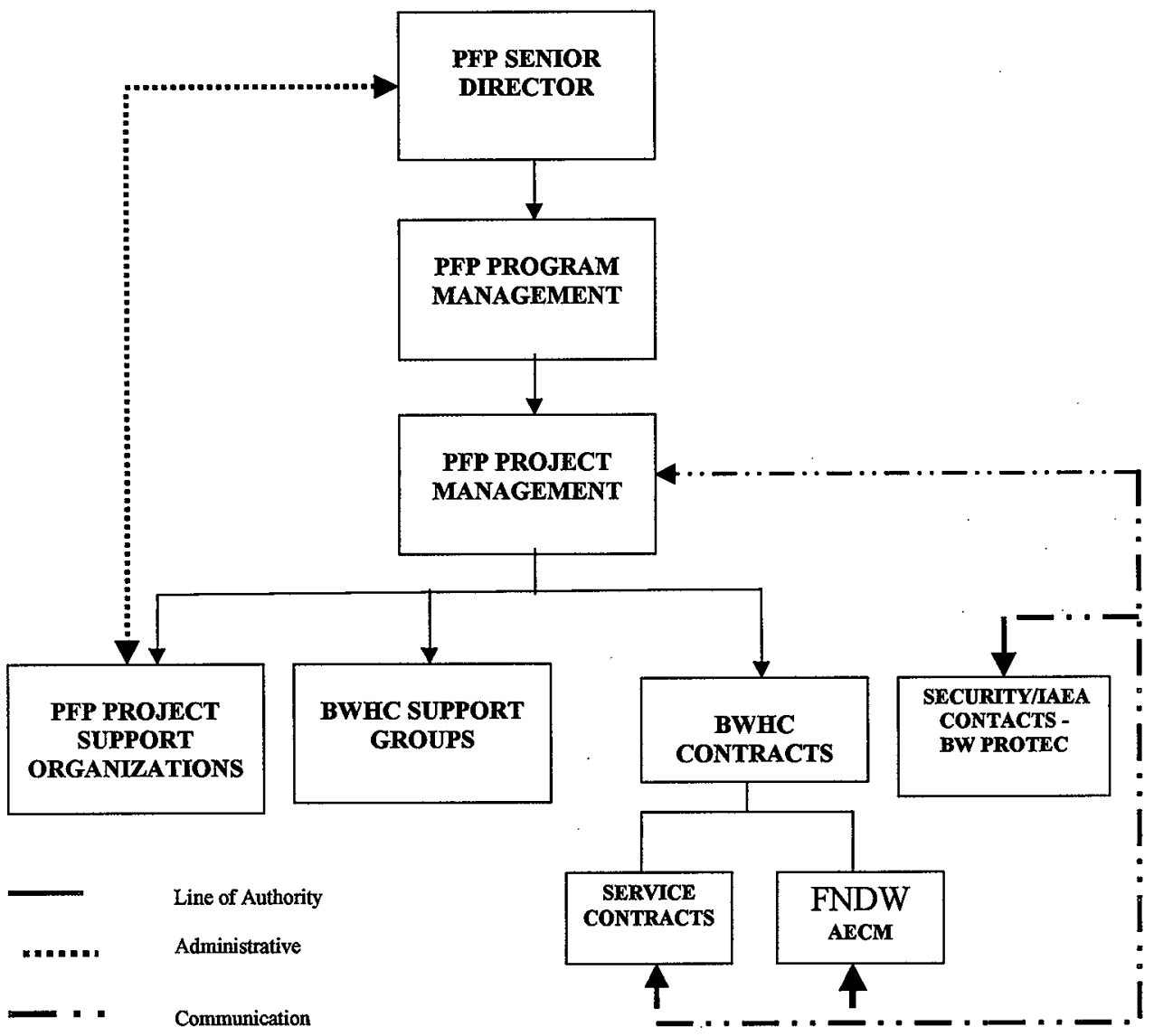


8. Quality Assurance

\section{A. Quality Assurance Document Hierarchy}

The BWHC Facility Stabilization Project Quality Assurance Program Plan (QAPP) (Reference FSP-MP-004) documents the BWHC organization, and functional responsibilities and interfaces for quality assurance (QA) and identifies procedures, instructions, and management systems to implement requirements appropriate to the BWHC work scope.

BWHC is currently responsible for the Facility Stabilization Projects and Advanced Reactor Transition. Due to the varied nature of BWHC Projects, the BWHC QAPP is a combination of an umbrella BWHC QAPP, which covers company activities and a set of Facility/Project specific QAPPs tailored to specific project tasks.

The PFP QAPP, FSP-PFP-5-8, Volume 2, Section 15.1, of the PFP Administration Mamual implements the QA requirements of Title 10, Code of Federal Regulations (CFR), Part 830.120, "Quality Assurance Requirements," and the Project Hanford Quality Assurance Program Description (QAPD), HNF-MP-599 and constitutes the specific PFP QAPP.

\section{B. Quality Assurance Organization and Interface}

The PFP structure, interfaces and levels of authority of the PFP organization are defined in the PFP Administration Mamual, FSP-PFP-5-8, Section A, "Organizational Charts," and general responsibilities are described in Section B, "PFP Management Positions/Team leaders - Key Functions."

\section{Quality Assurance Requirements}

PFP is subject to the requirements of Title 10, CFR, Part 830.120, "Quality Assurance Requirements," and shall comply with the applicable requirements described in the Project Hanford QAPD, HNF-MP-559. Appendix A, "QAPD Requirements Applicability Matrix," of the PFP QAPP identifies QAPD requirements that apply to each PFP organization.

\section{Systems Engineering Plan}

Due to the nature of the Remove SNM Material tasks and the level of negotiations required for the work, evaluations of options and work tasks are coordinated between RL, EM-64, BWHC and the Receiver Sites. Systems engineering support will be provided at PFP as it pertains to operations in the PFP. 
HNF-3752, Rev. 0

10. Security

The PFP security program addresses the following security aspects: Physical protection of SNM, nuclear material accountability \& control, access control requirements, human reliability program protection, shipments and movement of SNM and storage of SNM.

A. Personnel Security (clearances)

Authorized access to the process area will be controlled by positive identification that will require a "two-person rule." The two-person rule requires that at least two knowledgeable people in the Personnel Security Assurance Program be in the area when work is in progress.

Positive identification is performed at the Protected Area as well as at the Material Access Area.

B. Nuclear Material Accountability and Control

Domestic Safeguards Material Accountability and Control is applied to all SNM under Safeguards utilizing tamper indicating seals. Material surveillance procedures (two-person rule) are implemented utilizing personnel qualified under the Personnel Security Assurance Program in Category 1 SNM locations.

C. Physical Security

All material under safeguards will be protected under domestic security at all times. This will include utilization of locking devices for cubical storage and the use of transport wagons at all times. Material will be stored under vault protection when not attended.

11. Other Supporting Documentation

Other supporting documentation and plans will be prepared to support this subproject.
A. Regulatory Compliance plan
B. ALARA Plan
C. Characterization Plan
D. Readiness Assessment Plan
E. Shipper/Receiver Plans
F. Memorandum of Agreement 


$$
\text { HNF-3752, Rev. } 0
$$

Figure 3

\section{REMOVE SNM MATERIAL SHIPPING PROJECT SCHEDULE}

TO BE DEVELOPED AT A LATER DATE 


\section{DISTRIBUTION SHEET}

\begin{tabular}{|c|c|c|c|c|c|}
\hline \multirow{2}{*}{$\begin{array}{l}\text { To } \\
\text { Distribution }\end{array}$} & \multirow{2}{*}{\multicolumn{3}{|c|}{$\begin{array}{l}\text { From } \\
\text { PFP Program Management }\end{array}$}} & \multicolumn{2}{|c|}{ Page 1 of 1} \\
\hline & & & & \multicolumn{2}{|c|}{ Date December 28,1998} \\
\hline \multirow{2}{*}{\multicolumn{4}{|c|}{$\begin{array}{l}\text { Project Title/Work Order } \\
\text { Remove Special Nuclear Material Project Plan }\end{array}$}} & \multirow{2}{*}{\multicolumn{2}{|c|}{$\begin{array}{l}\text { EDT No. } 612495 \\
\text { ECN No. N/A }\end{array}$}} \\
\hline & & & & & \\
\hline Name & MSIN & $\begin{array}{c}\text { Text } \\
\text { With All } \\
\text { Attach. }\end{array}$ & Text Only & $\begin{array}{c}\text { Attach./ } \\
\text { Appendix } \\
\text { Only }\end{array}$ & $\begin{array}{l}\text { EDT/ECN } \\
\text { Only }\end{array}$ \\
\hline W.D. Bartlett & T5-50 & $\bar{X}$ & & & \\
\hline J. E. Bramson & T5-54 & $\mathrm{X}$ & & & \\
\hline T. A. Brown & T5-15 & $\mathrm{X}$ & & & \\
\hline G. J. Cox & T2-12 & $\mathrm{X}$ & & & \\
\hline F. R. Crawford & T5-50 & $\mathrm{X}$ & & & \\
\hline E. W. Curfman & T5-05 & $\bar{X}$ & & & \\
\hline M. W. Gibson & T5-55 & $\mathrm{X}$ & & & \\
\hline G. A. Glover & T4-20 & $\mathrm{x}$ & & & \\
\hline R. E. Heineman & T5-50 & $\mathrm{X}$ & & & \\
\hline K. R. Herzog & T2-12 & $\mathrm{X}$ & & & \\
\hline T. E. Huber & $\mathrm{T} 2-12$ & $\bar{x}$ & & & \\
\hline E. M. LaRock & T5-02 & $\mathrm{X}$ & & & \\
\hline C. A Meldrom & T4-19 & $\bar{x}$ & & & \\
\hline L. J. Olguin & N1-26 & $\mathrm{X}$ & & & \\
\hline A. L. Ramble & T5-54 & $\mathrm{x}$ & & & \\
\hline G. W. Reddick & N1-26 & $\bar{x}$ & & & \\
\hline R. D. Redekopp & T5-15 & $\bar{x}$ & & & \\
\hline L. L. Reed & T5-57 & $\mathrm{X}$ & & & \\
\hline P. E. Roege & T5-15 & $\mathrm{x}$ & & & \\
\hline P. K. Sato & T4-19 & $\frac{1}{x}$ & & & \\
\hline A. E. Schilling & T5-51 & $\mathrm{X}$ & & & \\
\hline J. C. Sinclair & T5-50 & $\bar{X}$ & & & \\
\hline D. R. Speer & T5-50 & $\mathrm{X}$ & & . & \\
\hline T.E. Stark & $\mathrm{T} 5-02$ & $\bar{x}$ & & & \\
\hline C. S. Sutter & T5-12 & $\mathrm{X}$ & & & \\
\hline M. D. Talbot & T5-15 & $\bar{X}$ & & & \\
\hline R. S. Wade & T5-54 & $\mathrm{X}$ & & & \\
\hline S. Zeller & T4-15 & $\mathrm{X}$ & & & \\
\hline Central Files & Bi-O7 & $x$ & & & \\
\hline & & & & & \\
\hline & & & $\cdot$ & & \\
\hline & & & & & \\
\hline & & & & & \\
\hline & & & & & \\
\hline & & & & & \\
\hline & & & & & \\
\hline & & & & & \\
\hline
\end{tabular}

